\title{
Analysis of Non-Point Source Pollution Features of Chao River Basin Based on the CMADS-Driven SWAT Model
}

\author{
Zhang Min ${ }^{1, \text { a }}$, Yang Long ${ }^{1, b^{*}}$, An Tongyan ${ }^{2, \mathrm{c}}$, Fan Qing ${ }^{2, \mathrm{~d}}$ \\ ${ }^{1}$ China Urban Construction Design Research Institute, Beijing, China \\ ${ }^{2}$ National Urban Environmental Pollution Control Engineering Technology Research Center, Beijing Municipal Research Institute of \\ Environmental Protection, Beijing, China
}

\begin{abstract}
By the China Meteorological Assimilation Driving Datasets for the Soil and Water Assessment Tool (SWAT) model (CMADS 1.0), this paper simulated the non-point source (NPS) pollution of Chao River Basin in the upper reach of Miyun Reservoir, and analyzed the spatial-temporal distribution pattern of nitrogen and phosphorus pollutants and the contribution rates of pollution sources. The major findings of the research are as follows. The CMADS V1.0-driven SWAT model shows good applicability to the study area. The simulation of the runoff, nitrogen and phosphorous pollution in the calibration period and the validation period has yielded a Nash-Sutcliffe efficiency (Ens) coefficient at $0.51 \sim 0.78$, and a coefficient of determination at $0.73 \sim 0.88$, which meets the model evaluation standards. The total nitrogen (TN) and total phosphorus (TP) pollution load in the flood season is considerably large, and the average inflow of TN and TP into the reservoir accounts for $60.62 \%$ and $75.15 \%$ the total annual inflow, respectively. The \#26 sub-basin marks the biggest $\mathrm{TN}$ and TP loads, and it is thus worth more attention from pollution control administrations. Overall, the TN and TP load in the lower reach of the basin are larger than the upper reach. NPS pollution is the major type of pollution caused by human production and life. The livestock and poultry farming as well as fertilizers, which are the main contributors to NPS pollution, are considered the focus of NPS pollution control.
\end{abstract}

\section{Introduction}

Water resources are strategic resources that play a significant role in national and social development; water resource protection and water pollution have drawn wide attention across the globe [1]. In these years, with fast economic growth and social progress, problems in the water environment bulk large, and to improve the water environment, countries have strengthened point-source pollution control, leaving non-point source (NPS) pollution as the major source of pollution to the water environment [2]. Recently, agricultural production has become the major contributor to NPS pollution [3], and large volumes of nitrogen and phosphorus pollutants, scoured by rainfalls and runoffs, lead to serious NPS pollution. To detect the features of NPS pollution is the precondition of NPS pollution control and also the basis for water pollution management in the basin.

The Soil \& Water Assessment Tool (SWAT) is a coupled model combining distributed hydro-logical with water quality and developed by USDA Agricultural Research Service applicable to continuous time-sequence simulation of quality of surface water and ground water. The SWAT model has been widely employed in research on NPS pollution globally. Huang et al. [4] simulated NPS pollution and runoffs of the Feilaixia Reservoir of Beijiang River by using the SWAT model, and the simulation result showed that the model performed well in simulating the NPS pollution of typical days of strong rainfalls and large precipitation. Yang et al. [5] optimized the nutrient circulation algorithm of the SWAT model, applied it to the Songtao Reservoir in Hainan province, analyzed the total nitrogen (TN) and total phosphorus (TP) loads under application of varied amounts of fertilizers, which increased applicability of the SWAT model. Lai et al. [6] simulated the NPS pollution in Henggang River basin in a karst region in Jiangxi Province, China, quantitatively evaluated the impact of such karst structures as ponors, subterranean rivers, and underground streams on the migration of major NPS pollutants like nitrogen and phosphorus as well as the spatial-temporal patterns of NPS pollution.

Data are the kernel of models, and the quality of the driving data directly affects the simulation results. The China Meteorological Assimilation Driving Datasets for the Soil and Water Assessment Tool (SWAT) model has achieved good performance in simulation of hydrological and water quality conditions in basins [7-8], but it was mostly applied to studies in basins in western China, and rarely was it used in research in the northern area in China. Through a case study on the Chao River basin in the upper reach of Miyun Reservoir, we employed the CMADS V1.0-driven SWAT model to simulate NPS pollution in the basin, and analyzed its applicability in the basin to explore the spatial-temporal distribution pattern of NPS pollution in the basin and contributions of different 
pollutants. The research is expected to provide a basis for protection of water resources and NPS pollution treatment in the basin, and offer parameters for simulation of NPS pollution in the Chao River basin.

\section{Overview of the study area}

Chao River $\left(40^{\circ} 19^{\prime} \sim 41^{\circ} 38^{\prime} \mathrm{N}, 116^{\circ} 7^{\prime} \sim 117^{\circ} 35^{\prime} \mathrm{N}\right)$, running across the northern and eastern regions of Beijing, belongs to the Hai River system, with its basin covering an area of $6227.5 \mathrm{~km}^{2}$ and an annual average runoff of 200 million $\mathrm{m}^{3}$. The river originates from Nanshan Mountain of Caonianzi Valley, Manchu Autonomous County of Fengning, Hebei Province, runs across Luan County, and enters Miyun County in Beijing from Beigu Entry, and joined by rivers including Andamu River, Qingshui River, and Hongmen River, it then runs into Miyun Reservoir around Xinzhuang Village; after it converges with Baihe River in Hecao Village in southwestern Miyun County, the confluence is called Chaobai River. The study area features a temperate monsoon continental semi-humid and semi-arid climate, with distinct divisions of seasons, and annual average temperature at $9 \sim 10^{\circ} \mathrm{C}$; the annual average precipitation of the study area is $488.9 \mathrm{~mm}$, with months from June to September marking the largest precipitation in the form of rain storms. The basin is located in the transition region from the North China Plain to the Inner Mongolian Plateau; the altitude declines from the northwest to the southeast, and the area is dominated by low- and medium-altitude mountains, with hills and mountains taking up over $80 \%$ of the total area. Also, boasting vegetation diversity, the studied area has a vegetation coverage rate above $70 \%$ [9].

\section{Data source and processing}

\subsection{Spatial data}

The digital elevation model (DEM) data with a resolution of STRM $30 \mathrm{~m} \times 30 \mathrm{~m}$ from the Geospatial Data Cloud of CAS were used in this study to extract geoinformation like the slope and aspect of the Chao River basin, perform subbasin division, and find the outflow paths. To ensure consistency of the input data of the SWAT model, all DEM data and data on land use and soil were projected onto the universal coordinates of WGS 1984 UTM Zone 48N, as shown in Figure 1.

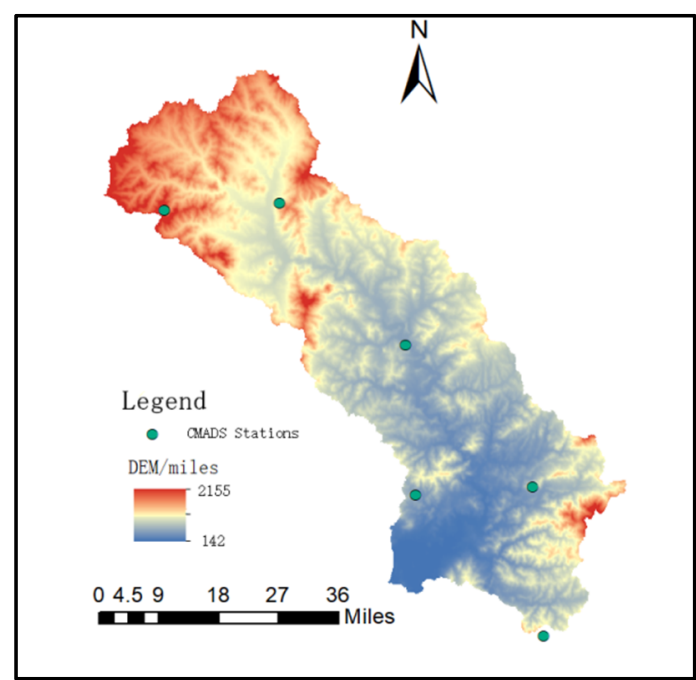

Fig. 1. Elevation distribution of Chao River basin.

\subsection{Data use data}

Data use data used in this study were LUCC remote sensing data released by the Chinese Academy of Sciences (CAS) in 2015 at a national proportional scale of 1:10. As per the land use categorization standards, eight land use types were identified in Chao River basin, including agricultural land, forest land, grassland, among which forest land took the largest share $(51.6 \%)$, as shown in Figure 2.

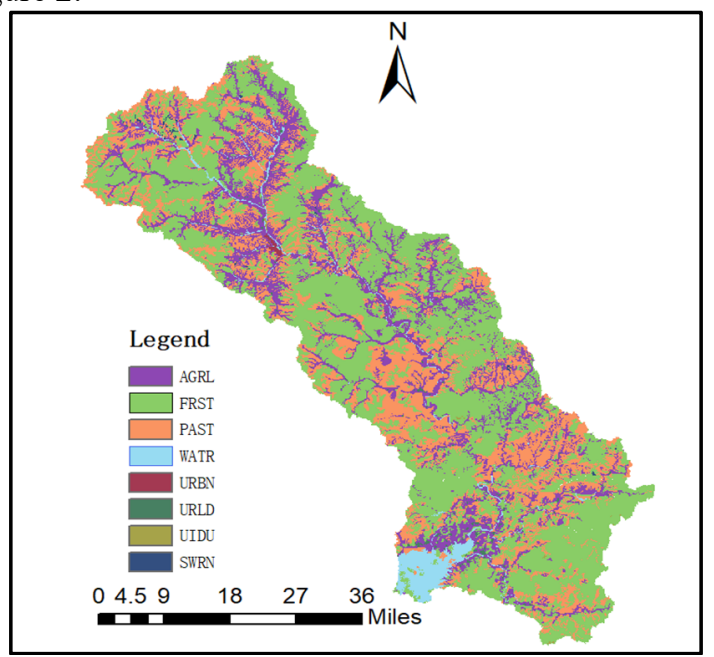

Fig. 2. Land use pattern of Chao River basin

\subsection{Soil data}

The soil type distribution data were data (at a proportional scale of $1: 100,000,000)$ from the HWSD database [10] built by the Food and Agriculture Organization (FAO) of the United Nations, the FAO1990 Soil Classification System [11], and the China Soil Classification System [12]. Among the soil parameters required by the SWAT model, soil thickness, organic carbon content and some other parameters were collected from the HWSD database, while the saturated hydraulic conductivity, effective water content and some others were calculated by the Soil-PlantAir-Water (SPAW) software developed by Washington University in the U.S. Figure 3 shows the result of soil 
type reclassification in the studied area.

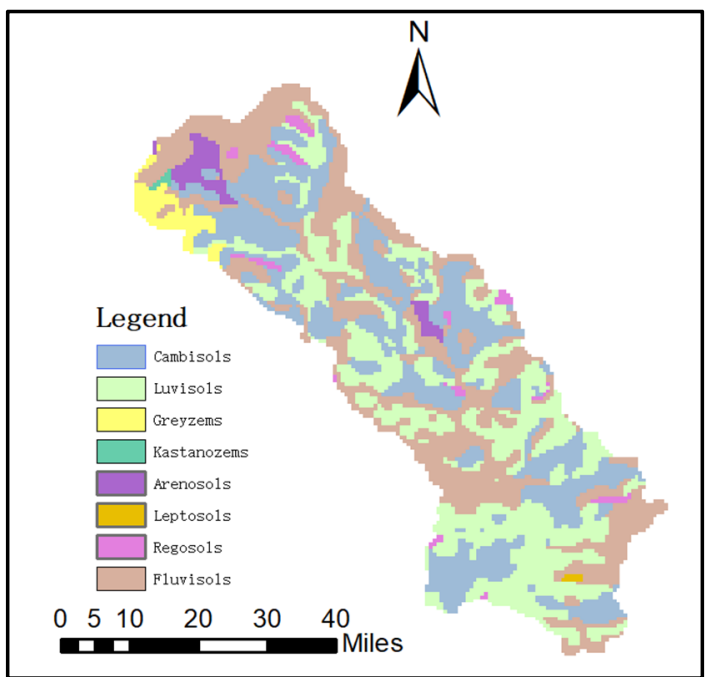

Fig. 3. Distribution of soil types in Chao River basin

\subsection{Hydrometeorological data}

The hydrometeorological data used in this study were from the CMADS V1.0 (http://westdc. westgis. ac. cn/) of National Cryosphere Desert Data Center within the time range of 2008 2018, with a spatial resolution of $1 / 3^{\circ}$ and involving parameters like average daily temperature, maximum/ minimum daily temperature, and daily accumulative precipitation. The CMADSV1.0 dataset provides data of six measuring stations in Chao River basin as hydrometeorological data inputs into the SWAT model. Table 1 shows the specific information of stations, and Figure 1 shows the distribution of these stations.

Table 1. Specifics of the CMADS stations in Chao River basin

\begin{tabular}{|c|c|c|c|}
\hline Station No. & Latitude $^{\circ}$ & Longitude ${ }^{\circ}$ & Elevation/m \\
\hline $125-170$ & 41.32 & 116.31 & 1405 \\
\hline $125-171$ & 41.32 & 116.64 & 1105 \\
\hline $124-172$ & 40.99 & 116.97 & 478 \\
\hline $123-172$ & 40.66 & 116.97 & 456 \\
\hline $123-173$ & 40.66 & 117.31 & 609 \\
\hline $122-173$ & 40.32 & 117.31 & 513 \\
\hline
\end{tabular}

\subsection{Other data}

The major crops in the basin are corn, walnut, and chestnut. The corns need $235 \mathrm{~kg} /$ hectare fertilizers per year, applied mainly in May and October; walnut and chestnut trees receive about $200 \mathrm{~kg}$ / hectare fertilizers per year. Urea is the main nitrogen fertilizer, and calcium phosphate is the main phosphatic fertilizer. Corns, walnuts and chestnuts are harvested in September [13].

The majority of the population in the basin are engaged in agriculture, and animal husbandry dominates its industrial structure; and as the industry is not developed in that area, the pollution is not severe. Industries and sewage treatment plants in the study area were analyzed and marked as non-point pollution sources. Non-point sources of pollution include discharge of agricultural production wastes, fertilizers and wastes from livestock and poultry breeding. The data were from the statistical year book of 2017 .

\section{Research method}

\subsection{SWAT modeling}

As per the DEM-generated river network and location of water outlets, the whole basin is divided into several subbasins for discretization, and through superposition of land use, soil and slope attributes in the sub-basins, one or several hydrological response units (HRUs) are generated. The location tables and measuring data tables for meteorological data are constructed, various types of meteorological data are input, and input files required for modelling are constructed, and after the data entry is completed, the inputs are modified on the model interfaces [14]. HRUs are the basic units of the SWAT model, and the runoff, sediment discharge, and nutrient pollution load of each HRU are calculated.

During the modelling process, a catchment area of $15,000 \mathrm{hm}^{2}$ are taken as the threshold to divide the Chao River basin into 34 sub-basins. The HRUs are defined as per the land use types, the soil types and the slope; the thresholds of land use, soil types, and slopes are set at 5\%, $5 \%$, and $20 \%$, respectively, and finally $756 \mathrm{HRUs}$ are extracted. Figure 4 shows the division of sub-basins.

The flow and water quality data measured at Xiahui Station where Chao River enters Miyun Reservoir from 2013 to 2017 are taken as the observed data; during the modelling process, the two years 2011 and 2012 are set as the pre-training period; 2013 2015 are set as the calibration period, and 2016 2017 are set as the validation period; the simulation scale is the month.

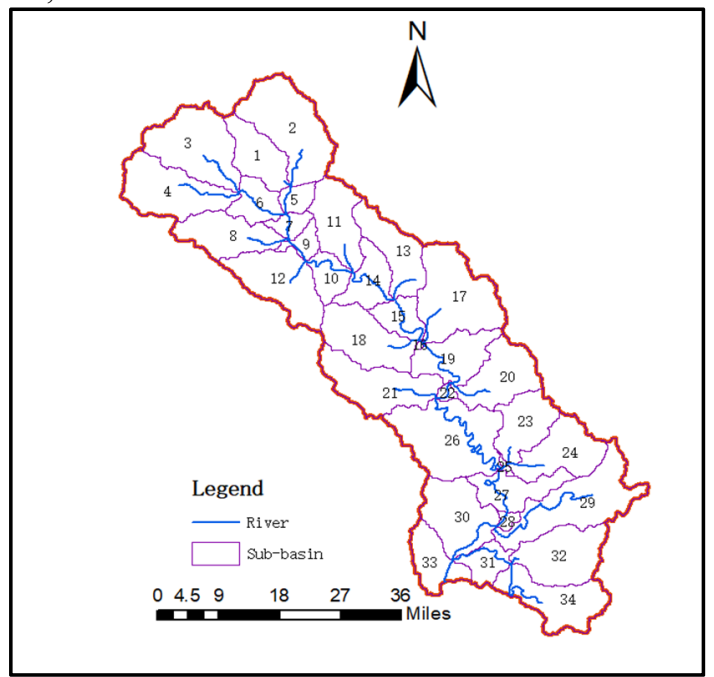

Fig. 4. Division of sub-basins of Chao River basin

\subsection{Model parameter calibration}

For calibration of the model parameters, the calibration should follow the sequence from the upper reach to the lower reach of the waterway, from the sub-branches to the trunk stream, from the water quantity to the water quality. The SWAT-CUP is the most widely-used SWAT model calibration software. In this study, the Sufi-2 calibration solution in the SWAT-CUP software was used for parameter calibration, and the parameter sensitivity was measured by three methods in the Sufi- 2 solution - one- 
at-a-time (OAT) sensitivity analysis, global sensitivity analysis, and dotty plots. Based on the empirical discussions in existing literature and the manual of SWATCUP, a large range of parameters are first selected, and according to the requirements of the Sufi- 2 algorithm, the parameter range are set and the objective function is selected to perform iteration of the recommended parameters and recommended parameter ranges, compare the simulation results with the measured values till the evaluation indicators meet the requirements. In this way, the final values of the parameters are identified.
The Nash-Sutcliffe coefficient of efficiency (Ens) and the coefficient of determination $\left(R^{2}\right)$ are selected as the applicable evaluation indicators. When $\mathrm{R}^{2}>0.75$, and Ens $>0.75$, it is considered that the model has good applicability; when $\mathrm{R}^{2} \leq 0.50$, and Ens $\leq 0.50$, the modelling result is considered not reliable; When the results are between the above two results, it is considered that the model is applicable and the result is satisfying [5]. The sequence of the sensitivity parameters and the optimal parameters are shown in Table 2.

Table 2. Parameter calibration results of the SWAT model

\begin{tabular}{|c|c|c|c|c|c|c|}
\hline \multirow[b]{2}{*}{ Sequence } & \multicolumn{3}{|c|}{ Runoff parameters } & \multicolumn{3}{|c|}{ Water quality parameters } \\
\hline & Symbol & Definition & $\begin{array}{c}\text { optimal } \\
\text { value }\end{array}$ & Symbol & Definition & $\begin{array}{c}\text { Optimal } \\
\text { value }\end{array}$ \\
\hline 1 & $\mathrm{CN} 2$ & $\begin{array}{l}\text { SCS runff } \\
\text { curve } \\
\text { coefficient }\end{array}$ & 0.121 & ERORGN & $\begin{array}{l}\text { Organic nitrogen } \\
\text { enrichment ratio }\end{array}$ & 0.110 \\
\hline 2 & ALPHA_BNK & $\begin{array}{l}\text { River channel } \\
\text { regulation } \\
\text { baseflow } \alpha \\
\text { factor }\end{array}$ & 0.050 & SOL_ORGN & $\begin{array}{l}\text { Initial organic } \\
\text { nitrogen } \\
\text { concentration in the } \\
\text { soil layer }\end{array}$ & 95.250 \\
\hline 3 & CH_K2 & $\begin{array}{l}\text { River channel } \\
\text { effective } \\
\text { hydraulic } \\
\text { conductivity } \\
\text { coefficient }\end{array}$ & 41.562 & ERORGP & $\begin{array}{l}\text { Organophosphorus } \\
\text { enrichment ratio }\end{array}$ & 0.50 \\
\hline 4 & GWQMN & $\begin{array}{l}\text { Underground } \\
\text { water baseflow } \\
\text { threshold } \\
\text { coefficient }\end{array}$ & 1907.861 & $\mathrm{CDN}$ & $\begin{array}{l}\text { Denitrification rate } \\
\text { coefficient }\end{array}$ & 1.147 \\
\hline 5 & ESCO & $\begin{array}{l}\text { Soil evaporation } \\
\text { compensation } \\
\text { coefficient }\end{array}$ & 0.892 & PPERCO & $\begin{array}{l}\text { Phosphorus flow } \\
\text { coefficient }\end{array}$ & 11.739 \\
\hline 6 & RCHRG_DP & $\begin{array}{l}\text { Deep aquifer } \\
\text { permeability } \\
\text { coefficient }\end{array}$ & 0.093 & SOL_NO3 & $\begin{array}{l}\text { Initial } \mathrm{NO}_{3} \\
\text { concentration in soil }\end{array}$ & $\begin{array}{l}\text { AGRL:3.328 } \\
\text { PAST:39.518 } \\
\text { FRST: } 1.855 \\
\end{array}$ \\
\hline 7 & REVAPMN & $\begin{array}{l}\text { Shallow } \\
\text { groundwater } \\
\text { runoff } \\
\text { coefficient }\end{array}$ & 7.324 & SOL_SOLP & $\begin{array}{l}\text { Initial soluble } \\
\text { phosphorus } \\
\text { concentration in } \\
\text { surface soil } \\
\end{array}$ & 23.052 \\
\hline 8 & CANMX & $\begin{array}{l}\text { maximum } \\
\text { canopy storage }\end{array}$ & 34.362 & NPERCO & $\begin{array}{l}\text { Nitrogen seepage } \\
\text { coefficient }\end{array}$ & 0.02 \\
\hline 9 & SOL_K & $\begin{array}{l}\text { Saturated } \\
\text { hydraulic } \\
\text { conductivity }\end{array}$ & -1.190 & SHALLST_N & $\begin{array}{l}\text { Contribution of } \\
\text { nitrate concentration } \\
\text { in groundwater to } \\
\text { waterflow in the } \\
\text { basin }\end{array}$ & $\begin{array}{c}\text { AGRL:718.0 } \\
98 \\
\text { PAST: } 826.50 \\
8 \\
\text { FRST: } \\
326.067 \\
\end{array}$ \\
\hline 10 & ALPHA_BF & $\begin{array}{l}\text { Baseflow } \\
\text { recession } \\
\text { coefficient }\end{array}$ & 0.045 & HLIFE_NGW & $\begin{array}{l}\text { Half-life of nitrate } \\
\text { in shallow aquifers }\end{array}$ & $\begin{array}{c}\text { AGRL: } 244.5 \\
70 \\
\text { PAST: } 74.446 \\
\text { FRST: } \\
112.469\end{array}$ \\
\hline 11 & GW_DELAY & $\begin{array}{l}\text { Groundwater } \\
\text { delay time } \\
\text { coefficient }\end{array}$ & 402.859 & N_UPDIS & $\begin{array}{l}\text { Nitrogen absorption } \\
\text { distribution }\end{array}$ & 101.785 \\
\hline 12 & CH_N2 & $\begin{array}{l}\text { Main channel } \\
\text { Manning } \\
\text { coefficient }\end{array}$ & 0.099 & PSP & $\begin{array}{l}\text { Phosphorus } \\
\text { availability index }\end{array}$ & 0.332 \\
\hline
\end{tabular}

Figure 5 compares the monthly average runoff simulation values in the basin and the actual values. As the figure shows, the efficiency coefficient $(E n s)$ and 
the coefficient of determination $\left(R^{2}\right)$ obtained in simulations during the calibration period and the validation period are both above 0.5 , which meets the standards for model e valuation, and the runoff simulation results are acceptable. The differences between the simulation values and the measured values are attributable to multiple factors, such as the spatial differences between regions in the basin that lead to difficulties in determination of parameters, errors in the model structure, and inaccurate data, etc.

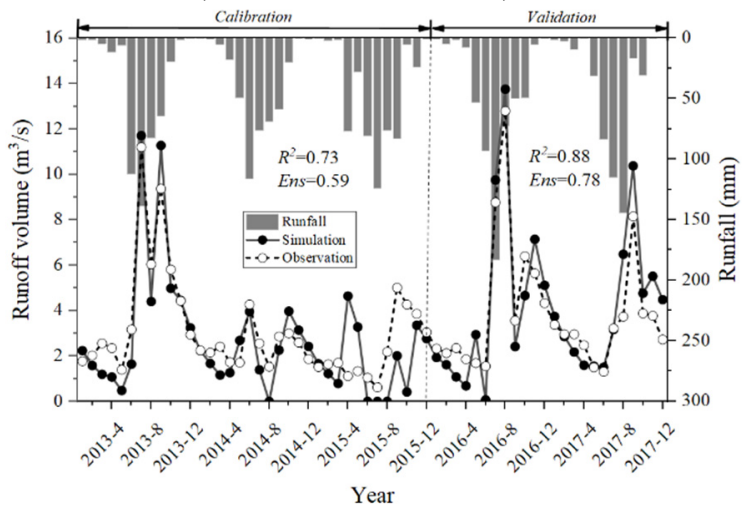

Fig. 5. Fitting between simulated runoff data and measured runoff data

\subsection{Validation of nitrogen and phosphorus pollution load simulation}

Compared with runoff simulation, the simulation of nitrogen and phosphorus loads is subject to more influencing factors and uncertainties. Therefore, the requirement for the accuracy of nitrogen and phosphorus load simulation is lower than that of the runoff simulation. Figure 6 shows the comparison between the simulated monthly TN load and the measured monthly TN load, and Figure 7 compares the simulated monthly TP load and the measured monthly TP load. The efficiency coefficient (Ens) and the coefficient of determination $\left(R^{2}\right)$ in the calibration period and the validation period are above 0.5 , which indicates reliability of the simulation result. The differences between the simulated TP load and the measured TP load are related to the precision degree of the runoff simulation. Meanwhile, uncertainties caused by migration of the pollutant loads are another contributor to the difference between the simulated values and the measurements.

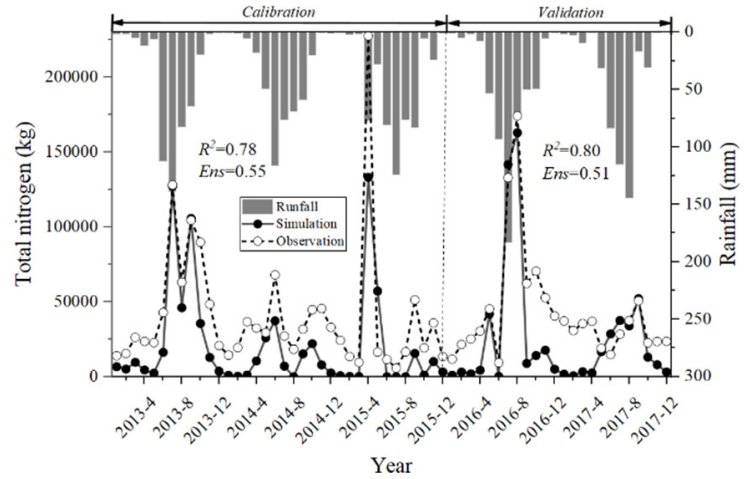

Fig. 6. Fitting between simulated TN and measured TN

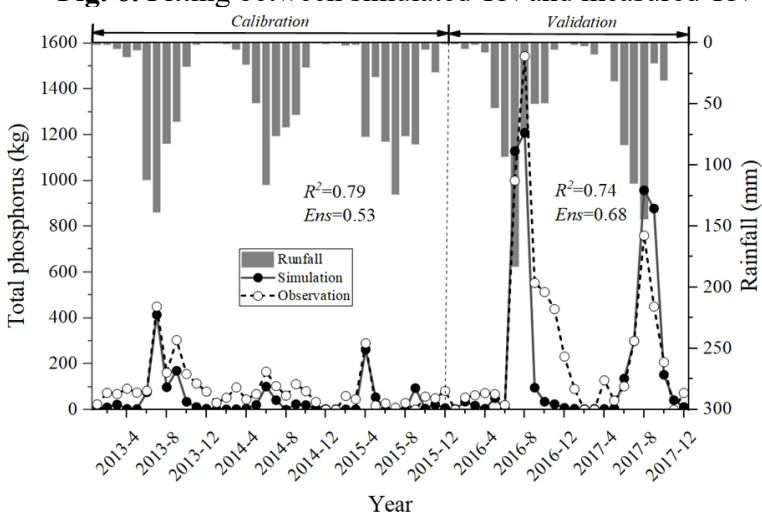

Fig. 7. Fitting between simulated TP and measured TP

\section{Result analysis}

\subsection{Temporal change patterns of non-point source pollution}

Table 3 shows the statistical analysis results of precipitation in the study area from 2013 to 2017. As the table shows, the average annual precipitation in Chao River basin is $414 \sim 522 \mathrm{~mm}$, with the flood season (from June to September) marking $80 \%$ of rainfalls across the year. Statistical analysis of the flood season in the basin and the NPS pollution across the year shows that the runoff occurs mainly during the flood season $(42 \% \sim 70 \%)$, and the average TN and TP pollution loads in the basin during the flood season take up a large proportion $(60.62 \%$ and $75.15 \%$, respectively) of the total loads. It is shown that the flood season is the critical period of NPS pollution and determines the severity of NPS pollution. This is related to the generation mechanism of NPS pollution: NPS pollution is mainly caused by runoff scouring, so in months of large precipitation, there are considerable soil erosion, leading to large TP and TN loads, as shown in Table 4 .

Table 3. Annual precipitation and temporal distribution across the year in Chao River basin

\begin{tabular}{|c|c|c|c|}
\hline Year & Annual precipitation (mm) & $\begin{array}{c}\text { Precipitation from June to } \\
\text { September (mm) }\end{array}$ & $\begin{array}{c}\text { Proportion of precipitation from } \\
\text { June to September in the annual } \\
\text { precipitation (\%) }\end{array}$ \\
\hline 2013 & 444.21 & 397.94 & 89.58 \\
\hline 2014 & 414.53 & 320.34 & 77.28 \\
\hline 2015 & 503.05 & 364.10 & 72.38 \\
\hline
\end{tabular}




\begin{tabular}{|l|l|l|l|}
\hline 2016 & 521.47 & 398.72 & 76.46 \\
\hline 2017 & 435.53 & 360.00 & 82.66 \\
\hline Mean & 448.15 & 362.12 & 80.80 \\
\hline
\end{tabular}

Table 4. Pollution loads in Chao River basin and the proportion of flood-season pollution loads in the yearly loads

\begin{tabular}{|c|c|c|c|c|c|c|}
\hline \multirow{2}{*}{ Year } & \multicolumn{3}{|c|}{ Runoff } & \multicolumn{2}{|c|}{ TN } & \multicolumn{2}{c|}{ TP } \\
\cline { 2 - 7 } & $\begin{array}{c}\text { Flood } \\
\text { season } \\
\left.\mathbf{( 1 0}^{\mathbf{8}} \mathbf{m}^{\mathbf{3}}\right)\end{array}$ & $\begin{array}{c}\text { Proportion of flood- } \\
\text { season runoff in the } \\
\text { annual total (\%) }\end{array}$ & $\begin{array}{c}\text { Flood } \\
\text { season } \\
\mathbf{( t )}\end{array}$ & $\begin{array}{c}\text { Proportion of flood- } \\
\text { season TN in the } \\
\text { annual total (\%) }\end{array}$ & $\begin{array}{c}\text { Flood } \\
\text { season } \\
\text { (t) }\end{array}$ & $\begin{array}{c}\text { Proportion of flood- } \\
\text { season TP in the } \\
\text { annual total (\%) }\end{array}$ \\
\hline 2013 & 2.35 & 69.14 & 357.19 & 69.71 & 2.96 & 88.05 \\
\hline 2014 & 1.07 & 52.80 & 219.01 & 53.34 & 1.61 & 81.53 \\
\hline 2015 & 2.91 & 42.11 & 226.06 & 35.69 & 1.69 & 33.32 \\
\hline 2016 & 3.05 & 62.30 & 638.43 & 73.51 & 6.25 & 93.02 \\
\hline 2017 & 2.16 & 56.12 & 389.14 & 70.83 & 4.20 & 92.88 \\
\hline Mean & 2.31 & 56.49 & 365.97 & 60.62 & 3.34 & 77.76 \\
\hline
\end{tabular}

\subsection{Spatial distribution pattern of NPS pollution}

Analysis of spatial distribution of NPS pollution shows that the upper reach and middle-and lower-reach of the basin mark larger TN loads, while the middle area of the basin suffers less pollution loads. Sub-basins numbered 1 , 3, 5, 12, 26 and 29 mark the largest TN load per unit area. Areas with large TP loads are distributed in the middleand lower-reach of the basin, where sub-basins numbered 26 and 34 show the largest TP loads per unit area. In sum, the sub-basin numbered 26 marks serious TN and TP loads, and it is thus worth attention for pollution treatment. Overall, the nitrogen and phosphorus load in the lower reach of the river is high, mainly because the lower reach is dominated by agricultural activities, boasts abundant arable land and grassland, with husbandry as its major economic growth source; and thus, the discharge of poultry and husbandry breading is large. Figure 8 shows the specifics.

(a)

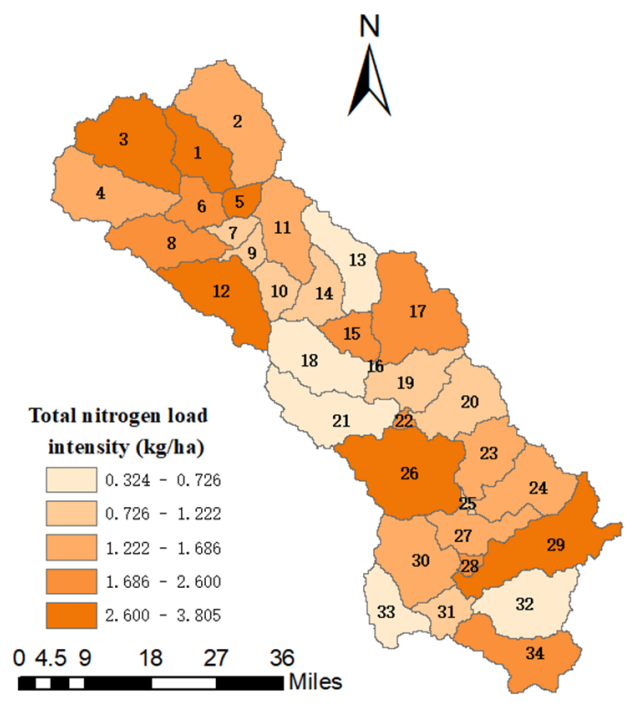

(b)

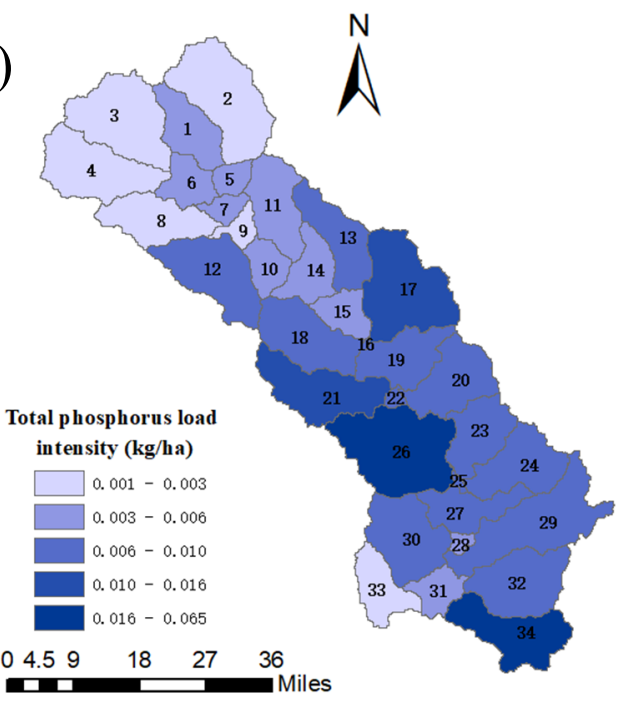

Fig. 8. Distribution of TN (a) and TP (b) loads in Chao River basin

\subsection{Contribution of NPS pollution}

The major sources of pollution in the basin include wastes from poultry and livestock farming, fertilizers, non-point source, point source pollution in rural areas, and the basin background value. The basin background value involves the soil background value and the basin water quality background value of the basin when no human-generated pollutants flow into the basin, which is related to such factors as the soil loss strength, the physical and chemical properties of the soil, the land form, climate, the previous ground surface and the accumulation of water sediments [16].

The changes in the pollution loads of the Chao River basin with inflow of pollutants and without inflow of pollutants are simulated separately to calculate the contribution of different pollution sources to the pollution loads in Miyun Reservoir. Figures 9 and 10 show the contribution of TN, TP and other pollutants. As the figures show, the point-source pollutants, fertilizers, domestic point-source pollution, and the nutrient pollutants caused 
by livestock and poultry farming account for $35 \%$ of the total pollution load in the basin. Part of these pollutants are generated by human production activities and life, and can be controlled within an acceptable range. Among the human-controlled nutrient pollutant loads, non-point source pollution (fertilizers, domestic wastes, livestock and poultry farming wastes) TN and TP loads account for $97.6 \%$ and $99.8 \%$ of the total pollution loads. Thus, to improve the water quality of the basin, we should strengthen non-point source pollution control, and pay specific attention to non-point source pollution caused by livestock and poultry farming, and fertilizer application, which are the major contributor to NPS pollution.

Besides, the NPS pollution load caused by background value of the basin is unnecessarily uncontrollable. By "grain for green" measures according to the local conditions, we can protect, restore and improve the ecology, strengthen administration of land use, reduce soil and water loss, and considerably cut the pollution loads.

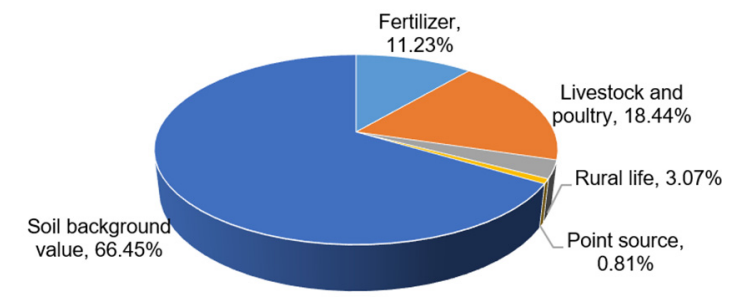

- Fertilizer " Livestock and poultry " Rural life " Point source - Soil background value

Fig. 9. Contribution of different pollutants to the TN in Chao River basin

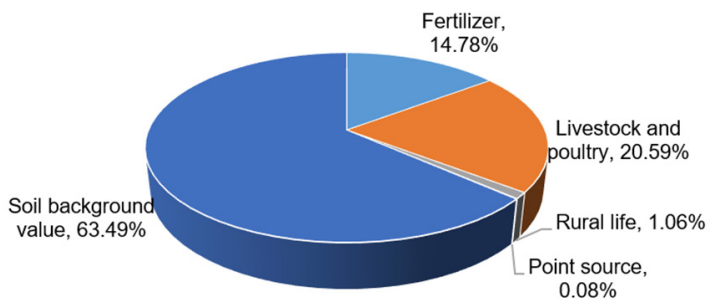

- Fertilizer " Livestock and poultry " Rural life " Point source " Soil background value

Fig. 10. Contribution of different pollutants to the TP in Chao River basin

\section{Conclusion}

The CMADS V1.0-driven SWAT model was employed to simulate NPS pollution in the Chao River basin of the upper reach of Miyun Reservoir, the applicability of the SWAT model was explored, and the spatio-temporal distribution pattern of nitrogen and phosphorus, as well as the contribution of different pollutants to the total pollution loads was analyzed. The major conclusions of the study are as follows.

(1) For the modelling, 2011 2012 were selected as the pretraining period, 2013 2015 as the calibration period, and 2016 2017 as the validation period. The runoff and TN, TP pollution loads in Chao River basin were simulated, and the result showed that the Nash-Sutcliffe efficiency (Ens) of the runoff, TN, and TP simulation during the calibration and validation periods was
$0.51 \sim 0.78$, and the coefficient of determination (R2) was $0.73 \sim 0.88$, which met the model evaluation standards, and indicated that the proposed SWAT model had good applicability to the study area.

(2) NPS pollution was mainly driven by runoff scouring. The flood-season runoff accounted for $42 \sim 70 \%$ of the total annual runoff in the study area, and the floodseason TN and TP loads account for a large proportion (60.62\% and $75.15 \%$, respectively) of the total TN and TP loads into the Miyun Reservoir. It indicated that the flood season is the critical period for generation of NPS pollution and plays a decisive role in the overall NPS pollution.

(3) The upper reach and middle- and lower-reach mark larger TN loads in Chao River basin, and the middle area has a lower TN load; the areas with large TP loads are in the middle and lower reaches of the basin. In sum, the subbasin NO. 26 shows the severest TN and TP loads, and thus is worth more attention in treatment; overall, the lower reach of the basin has a higher TN and TP load than other regions, which are attributable to agricultural activities, livestock and poultry farming.

(4) The major sources of pollution in Chao River basin were livestock and poultry farming, fertilizer loss, nonpoint source and point-source agricultural wastes, and the basin background values, among which the basin background made the largest contribution to the pollution loads in the basin, and can be controlled by "grain to green" measures. NPS pollution, the major form of pollution induced by human activities, were mainly caused by livestock and poultry farming as well as fertilizer application, and thus these causes were worth attention in pollution treatment.

One of shortcomings of the study is that the analysis results of NPS pollution distribution features of the basin were not combined with the administration region, and secondary processing of the results was needed for realworld application. This is because the results of the SWAT model were obtained based on the hydrological units and did not respond to the administration divisions. Moreover, the resolution and accuracy of the input data need to be improved, and the SWAT model per se is to be optimized; and as it is difficult to obtain the model parameters, the simulation results feature uncertainty, and hence the model is worth further research.

This study is a phased research result of the Youth Science Foundation of China Construction Technology Consulting Co., Ltd. "Optimal management and model optimization of non-point source pollution in typical basins - A case study of Chaobai River basin" (Z2019Q21).

\section{References}

1. Chen Y., Zhao Y. X., Zhao Y., Wang D., Bai H., Guo H. C. (2019) Research on nitrogen and phosphorus pollution loads in Bailihu Lake basin based on SWAT model. Journal of Peking University (Natural Science Edition), 55(06): 1112-1118. 
2. THARME R E. (2003) A global perspective on environmental flowassessment: emerging trends in the development andapplication of environmental flow methodologies for rivers. River research and applications, 19(5): 397-441.

3. Cheng H. G., Yue Y., Yang S. T. et al. (2005) Estimation and analysis of non-point source pollution load in Yellow River basin. Acta Scientiae Circumstantiae, 26(26): 384-391.

4. Huang G. R., Chen X. L., Ren X. W. (2019) Analysis and simulation of non-point source pollution features of typical basins in Feilaixia Reservoir of Beijiang River. Water Resources Protection, 35(04): 9-16+62.

5. YANG S., DONG G., ZHENG D., et al. (2011) Coupling Xin'anjiang model and SWAT to simulate agricultural non-point source pollution in Songtao watershed of Hainan, China. Ecological Modelling, 222( 20/21/22): 3701-3717.

6. Lai G. Y., Yi S. K., Liu W. Et al. (2018) Simulation of non-point source pollution in karst regions based on the modified SWAT model: A case study of Heigang River basin. Journal of Lake Sciences, 30 (6): 1560-1575.

7. Meng X Y,Wang H, Lei X H, et a1. (2017) Hydrological modeling in the Manas River Basin using soil and water assessment tool driven by CMADS. Tehnicki Vjesnik-Technical Gazette, 24(2): 525-534.

8. Meng X.Y., Zhang X.S., Yang M.X., et al. (2019) Application and Evaluation of the China Meteorological Assimilation Driving Datasets for the SWAT Model (CMADS) in Poorly Gauged Regions in Western China. Water, 11(10).

9. Lu L., Pan X. Y., Li W., Cui Q. M., Li J. (2017) Analysis of change patterns of runoff and precipitation in Chao River basin. Beijing Water Affairs, (01): 9-14.

10. Fischer G F, Nachtergaele S, Prieler H T, et al. (2008) Globalagro-ecological zones assessment for agriculture (GAEZ 2008). Laxenburg: IIASA.

11. The Food and Agriculture Organization of the United Nations. (1996) World Soil Resources Reports: FAO/UNESCO Soil Map of the World (Modified). Rome: FAO. 60.

12. Chinese Soil Taxonomy Research Group. (1992) Chinese Soil Taxonomy. Science Press, Beijing.

13. Qiu J. L., Shen Z.Y., Hou X.S., Xie H., Leng G.Y. (2020) Evaluating the performance of conservation practices under climate change scenarios in the Miyun Reservoir Watershed, China. Ecological Engineering, 143: 105700.

14. Ma Y. L., Bai Z. H., Ao T. Q. (2019) Analysis of non-point source pollution features in Lu County of Longxi River based on the SWAT model. China Rural Water and Hydropower, (07): 103-109.

15. Zhai X. Y., Xia J. Zhang Y. Y. (2011) Runoff simulation of Shali River basin based on SWAT model. Journal of Wuhan University (Engineering Science Edition). 44(2): 142-145.

16. Pang J. P. (2007) Distributed simulation of nonpoint source pollution. Beijing Normal University, Beijing. 